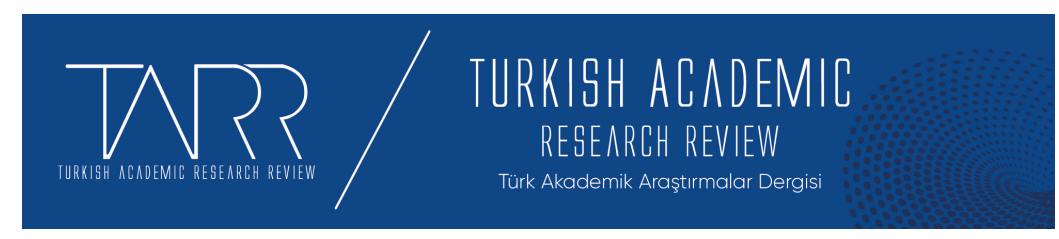

e-ISSN: 2602-2923 Yll/Year: 2021 Cilt/Volume: 6 Sayı/Issue: 2

\title{
Müzikle Tedavi: Tarihi, Gelişimi, Bağımlılıklarda Uygulanışı Ve Türkiye'deki Müzik Terapi Uygulamaları
}

Musıc Healıng: History, Development, Applicatıon In Addictıons And Music Therapy Applications In Turkey

\section{Mustafa YILDIRIM}

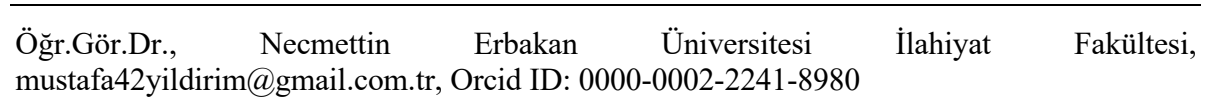

\begin{tabular}{r|l} 
Makale Bilgisi & Article Information \\
Makale Türü - Article Type & Araştırma Makalesi / Research Article \\
Geliş Tarihi - Date Received & 9 Mayıs / May 2021 \\
Kabul Tarihi - Date Accepted & 23 Haziran / June 2021 \\
Yayın Tarihi - Date Published & 25 Haziran / June 2021 \\
Yayın Sezonu & Nisan - Mayıs- Haziran \\
Pub Date Season & April - May - June
\end{tabular}

Atıf / Cite as: Yıldırım, M. (2021). Müzikle Tedavi: Tarihi, Gelişimi, Bağımlılıklarda Uygulanışı Ve Türkiye'deki Müzik Terapi Uygulamaları/Musıc Healıng: History, Development, Application In Addictions And Music Therapy Applications In Turkey. Turkish Academic Research Review, 6 (2), 477-497. Retrieved from https://dergipark.org.tr/tr/pub/tarr/issue/62824/935092

Intihal / Plagiarism: Bu makale, en az iki hakem tarafından incelenmiş ve intihal içermediği teyit edilmiştir. / This article has been reviewed by at least two referees and confirmed to include no plagiarism. https://dergipark.org.tr/tr/pub/tarr

Copyright (C) Published by Mehmet ŞAHIN Since 2016- Akdeniz University, Faculty of Theology, Antalya, 07058 Turkey. All rights reserved.

Turkish Academic Research Review - Türk Akademik Araştırmalar Dergisi 


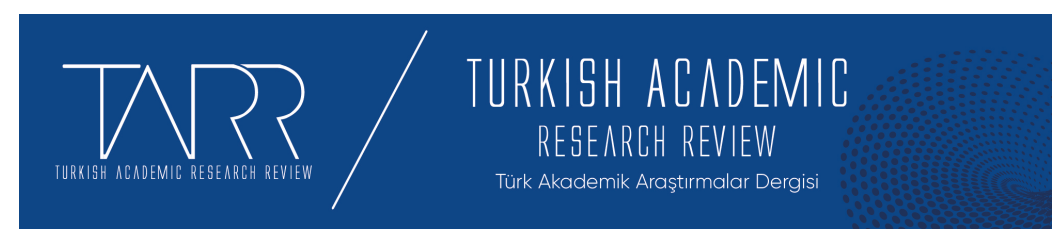

e-ISSN: 2602-2923 Yll/Year: 2021 Cilt/Volume: 6 Sayı/Issue: 2

\title{
Müzikle Tedavi: Tarihi, Gelişimi, Bağımlılıklarda Uygulanışı Ve Türkiye'deki Müzik Terapi Uygulamaları
}

\author{
Mustafa YILDIRIM
}

\section{$\ddot{O} \mathbf{z}$}

İnsanoğlu tarih boyunca müzikten her şekilde yararlanmıştır. Müzik, savaşlarda insana cesaret vermiş, düğünlerde eğlendirmiş, kötü ruhları uzaklaştırmada, inanca göre tanrı ya da tanrılara sesini duyurmada vasıta olarak kullanılmıştır. Müziğin en etkin rolü ise tarih boyunca neredeyse bütün medeniyetlerde şifa maksatlı olmasıdır. Yaklaşık 6000 yıllık bir müzikle tedavi geleneği birikimi olan ve ilk defa hastane ortamında müziği tedavi maksatlı kullanan Türklerdir. Makamların insan üzerindeki etkileri çalışılmış, farklı hastalıklara farklı müzik makamları tedavide uygulanmıştır. Çin, Hint, Mısır gibi birçok medeniyet müziğin şifa gücünü keşfetmiş, ruhsal kaynaklı olduğunu düşündükleri hastalıklarda müziği tedavi amaçlı kullanmışlardır. $\mathrm{Bu}$ araştırmada müzik terapilerinin tarihi, gelişimi, metotları, madde ve davranış bağımlılığında tedavideki yeri incelenmiştir. Bu kapsamda müziğin ruh ve sinir hastalıklarının yanında madde bağımlıların tedavisinde de kullanılabilirliği ulaşılabilen yazılı kaynaklar doğrultusunda araştırılmıştır. Türk kültüründe bugün gelinen noktada müzikle terapi konusu ele alınmış, akademik çalışmaların Türk Müziği makam bilgilerine göre yapılıp yapılmadığı irdelenmiştir. Araştırma sonucunda; teknoloji ile birlikte müzikle terapi metodları geliştikçe müziğin tedavide kullanım alanı ve çeşitliliğinin arttığı, müzik terapilerinin madde ve davranışsal bağımlılarda etkin bir rol aldığı ve hastanelerde müzik terapilerini ilk başlatan Türk İslâm medeniyetinin bugün gelinen noktada yetersiz olduğu kanaatine varılmıştır. Müzik terapilerinde kullanılacak müziklerin Türk Müziği formlarından olması ve makamların tedavideki yerini araştırmış olan akademisyenlerden faydalanılması gerektiği önerilmiştir. Çalışmamız nitel çalışmadır ve tarama modeli kullanılmıştır. Evrenimiz; müzik, örneklemimiz; müzik terapileridir.

Anahtar Kelimeler: Müzik, müzikle tedavi, bağımlılık, müzik terapi, madde bağımlılığı,

Music Healing: History, Development, Application In Addictions And Music Therapy Applications In Turkey

\begin{abstract}
Mankind has benefited from music throughout history. Music was used as a means to encourage people in wars, entertain them at weddings, ward off evil spirits, and make their voices heard by god or gods according to belief. Music has the most effective role for healing purposes in almost all civilizations throughout. It is Turks who have an accumulation of about 6000 years of musical healing tradition and use hospital music for therapeutic purposes. Authorities have been studied and applied different music tones to different diseases. Many civilizations such as China, India and Egypt discovered the healing power of music and used music for therapeutic purposes in diseases that they thought were spiritually originated. In this study, the history, development, methods, and role of music therapies in treatment of substance
\end{abstract}

Turkish Academic Research Review - Türk Akademik Araştırmalar Dergisi 
478 Müzikle Tedavi: Tarihi, Gelişimi, Bağımlılıklarda Uygulanışı Ve Türkiye'deki Müzik Terapi Uygulamaları

and behavior addiction were examined. In this context, the usability of music in the treatment of substance addicts as well as mental and nervous diseases was investigated in accordance with available written sources. At the point reached today in Turkish culture, the subject of music therapy has been discussed, and it has been examined whether academic studies are carried out according to Turkish Music makam information. As a result of the research; It has been concluded that, as music therapy methods develop with technology, the area of using and diversity of music in treatment has increased, music therapies have taken an active role in substance and behavioral addicts, and the Turkish Islamic civilization, which first initiated music therapies in hospitals, is insufficient at the point reached today. It has been suggested that the music to be used in music therapies should be from Turkish Music forms and academicians who have researched the place of makams in treatment should be utilized. Our study is a qualitative study and scanning model was used. Our universe; music, our sample; are music therapies.

Keywords: Music, Music therapy, Addiction, Music therapy, Substance addiction.

\section{Structured Abstract}

Mankind has benefited from music throughout history. Music was used as a means to encourage people in wars, entertain them at weddings, ward off evil spirits, and make their voices heard by god or gods according to belief. Music has the most effective role for healing purposes in almost all civilizations throughout. In the Pythagoras school, music was used more effectively for healing and religious rituals. Many civilizations such as China, India and Egypt discovered the healing power of music and used music for therapeutic purposes in diseases that they thought were spiritually originated. Authorities have been studied and applied different music tones to different diseases. Music, in Islamic art culture, was evaluated in terms of its effect on listening and spiritual feelings rather than its affecting the soul by shaping according to the hadiths and sunnahs of the Prophet and Qoran. Kindî was the first Islamic scholar who started music scientifically for therapeutic purposes. It is Turks who have an accumulation of about 6000 years of musical healing tradition and use hospital music for therapeutic purposes. Farabi and Ibn Sinâ (Avicenna), one of the Turkish Islamic philosophers, investigated the effect of musical tone on the treatment of illnesses and determined the effects of musical tones on people. As a result of their work, music therapy hospitals were opened in the Seljuk and Ottoman States. Music therapy in clinical settings gained momentum in America after World War II. Until today, success has been achieved in many studies conducted in clinical settings in psychological diseases. The most striking of these achievements is substance addiction. In this study, the history, development, methods, and role of music therapies in treatment of substance and behavior addiction were examined. In this context, the usability of music in the treatment of substance addicts as well as mental and nervous diseases was investigated in accordance with available written sources. At the point reached today in Turkish culture, the subject of music therapy has been discussed, and it has been examined whether academic studies are carried out according to Turkish Music makam information. As a result of the research; It has been concluded that, as music therapy methods develop with technology, the area of using and diversity of music in treatment has increased, music therapies have taken an active role in substance and behavioral addicts, and the Turkish Islamic civilization, which first initiated music therapies in hospitals, is insufficient at the point reached today. It has been suggested that the music to be used in music therapies should be from Turkish Music forms and academicians who have researched the place of makams in treatment should be utilized. Our study is a qualitative study and scanning model was used. Our universe; music, our sample; are music therapieswhether academic 
studies are carried out according to Turkish Music makam information. As a result of the research; It has been concluded that, as music therapy methods develop with technology, the area of using and diversity of music in treatment has increased, music therapies have taken an active role in substance and behavioral addicts, and the Turkish Islamic civilization, which first initiated music therapies in hospitals, is insufficient at the point reached today. It has been suggested that the music to be used in music therapies should be from Turkish Music forms and academicians who have researched the place of makams in treatment should be utilized. Our study is a qualitative study and scanning model was used. Our universe; music, our sample; are music therapies.

\section{Giriş}

Kulağa hoş gelen nağmeler veya güzel nağmeler bütünü olarak adlandırılan müziğin ortaya çıkış tarihini araştıran filozoflar, bu güne kadar kesin bir başlangıç zamanı tespit edememişlerdir.. İnsanlığın tarihiyle eşdeğer olarak kabul edilen müzik, kültürlerin gelişimiyle birlikte karşımıza zamanla bir ilim olarak çıksa da insan ihtiyacına matuf fonksiyonları hep aynı kalmıştır. Bir yanıyla insanın duygularını dışavurum, bir yanıyla eğlence, bir yanıyla tedavi ve bir yanıyla insanın tanrı veya tanrılarına sesini duyurma aracı olarak kullanılan müzik, bu günde aynı fonksiyonlarını devam ettirmektedir. Eskiçağ tarihine müziğin kullanım amaçları açısından genel olarak baktığımızda, Hind, Türk, Çin, Sümer ve Mısırlılar gibi bir medeniyete sahip toplumların yanında, ilkel kabile diye tanımlanan kült topluluklarda da aynı olduğunu görürüz.

Eskiçağda müzik, insanın ruhsalına yönelik inanç eksenli kullanımda daha yaygındır. İlkel kabilelerdeki inanışa göre her varlığın kendine ait bir sesi ve şarkısı vardı. İnsanın tepki göstereceği o ses ve şarkı, büyücü tarafından bulunarak içindeki kötü ruhlar bu şekilde çıkarılarak tedavi olunacağı düşünülürdü. Hristiyanlıkta kilise ileri gelenleri müziği ruhsal hastalıklara karşı tedavi amaçlı kullanmışlardır. Türklerdeki şaman, kam gibi kişilerde olduğu gibi Hristiyanlıkta azizlerin de özel manevi güçlerinin olduğu düşünülürdü. Hristiyanlık anlayışı içinde de dinî hüviyetli müzik hastalıkların tedavisinde kullanılıyordu (Güvenç, 1985, 3).

Türklerin müzikle tedavi şekli yaklaşık 6000 yıllık bir geçmişe sahiptir. Tonguzlar'ın “şaman”, Altay Türklerinin “kam”, Yakutların “oyun”, Kırgızların "bahşı”, Oğuzların “ozan” adını verdikleri ve şâirliğin dışında sihirbazlık, rakkaslık, hekimlik ve mûsikîşinâsılı gibi birçok vasıfları da bulunan bu kişilerin halk üzerinde büyük etkisi vardı. Türk kamları, ruhların yardımını istemek veya onlarla mücadele etmek için ateşler yakıp davullar çalarak ve sihirli nağmeler terennüm ederek, temsîlî rakslarla âyinler yaparlardı. Müzik dâhil hastaları tedavi etmede bu hekimlerin mistik gücünün olduğu kabul edilirdi (Demirci, 2021, 26).

Turkish Academic Research Review - Türk Akademik Araştırmalar Dergisi 
480 Müzikle Tedavi: Tarihi, Gelişimi, Bağımlılıklarda Uygulanışı Ve Türkiye'deki Müzik Terapi Uygulamaları

Mısır tarihinde de müziğin Türklerde olduğu gibi mistik yönüyle kullanımı hiyeroglif resimlerden anlaşılmaktadır. "Günümüze kadar ulaşan kabartmalardan müziğin hayatın ne kadar içinde olduğunu anlayabiliyoruz. Kahire'nin büyük hastanelerinden birinde hastalara operasyondan önce müzik dinletilir, böylece hastaların operasyondan önce büyük bir güç kazandıklarına ve kendilerini daha kuvvetli hissettiklerine inanılırdı" (Kaygısız, 1999: 55).

Filozoflar müziğin tarifini yaparken insan üzerindeki etkilerinden de bahsetmişlerdir. Konfüçyus; “Müzik yapıldığında kişilerarası ilişkiler düzelir, gözler parlar, kulaklar keskin olur. Kanın vücuttaki hareketi ve dolanımı sakinleşir.” diyerek müziğin tedavi maksatlı kullanılabileceğine vurgu yapmıştır (Ak, 2013: 140). Ludwig van Beethoven, müziği Allah'a en ziyade yaklaştıran bir unsur oluşundan ve bütün felsefelerin üstünde olduğundan bahsederek mûsikînin önemini ve amacını ortaya koymaktadır. Goethe, müziğin rûha hitâb ettiğini ve rûhun da kendisini en iyi şekilde ancak müzikle ifade edebileceğini belirtmektedir (Turabi, 2021, 11).

İslam kültür sanatında müzik, Kur'ân-1 Kerîm, Hz. Peygamber'in hadisleri ve sünnetlerine göre şekillenerek, nefse hitâb eden yönünden daha çok dinlenme ve manevi duygulara hitap eden yönüyle değerlendirilmiştir. İslâm medeniyetinde müziğin felsefesi ile ilgilenen mutasavvıflar, müziğin insana Allah (c.c) tarafindan verilen ilâhî bir lütuf olduğunu düşünerek zikirleri esnasında transa geçme vasıtası olarak kullanmışlardır. İlk mutasavvıflardan olan Zünnûn el-Mısrî, müziğin ilâhî kaynaklı olduğunu, dinlenildiğinde hakikat mertebesine çıkardığını, nefs ile dinlendiğinde zındıklık derecesine düşüreceğini belirtmiştir. Mevlana Celaleddin Rumi: "Mûsikî, Allah âşıkları için ruhun gıdasıdır; zîrâ onda sevgiliye yani Allah’a(c.c) kavuşma ümidi mevcuttur." söylemiyle zikir esnasında Mevlevilerin müzikten faydalanarak vecd hâli denilen transa geçme halini hızlandırmada etkin bir araç olarak kullanmalarına yol açmıştır. (Gönül, Yıldırım, 2017, 267).

\section{Tarihte Müziğin Şifâ Maksatlı Kullanılmaya Başlanması}

Dini Kaynaklarda Hz. Davud'un (a.s) ibadetlerini, yetiştirdiği musikişinaslarla müzik eşliğinde yaptığı bilinmektedir (Düzenli, 2014, 60). Pythagoras müziği, insan ruhsalının ve dinî amaçlarla kullanımının merkezinde düşünmüştür. Bundan dolayı Pythagoras okulunda müzik, tedavi amaçlı ve dinî ritüellerde daha etkin kullanılmıştır (Tarhan, 2020, 205). 
Abbasi döneminde müziğin eğlence anlayışından bilim anlayışına geçişte ilk bilimsel eserler veren ve ilk İslâm filozofu olan Kındî, Pitagorasçı bir anlayışla, gök cisimleriyle müzik arasında güçlü bağlar tesis etmeye çalışmıştır. İslâm sanat kültüründe müzik kuramı üzerine ilk çalışmaları başlatan Kındî, müziği tedavi amaçlı bilimsel olarak ilk başlatandır (Turabi, 2021, 39). Bu doktrini devam ettiren Türk filozoflarından Farabi ve İbni Sinâ da müzik nazariyatını araştırırken sesin gücünü ve insan üzerindeki etkisini incelemiştir. Yaptıkları çalışmalar ile Kındî’nin başlattığı uygulamaları geliştirerek müzikle tedavi konusunda çı̆̆ır açmışlardır. Farabi hastalıkları tedavi etmede makamların etkisini araştırarak makamların insanlar üzerinde bıraktığı tesirleri belirlemiştir. Yaptığı çalışmalara göre rast makâmı insana sevinç, rehâvi ağlama, kuçük hüzün ve elem, büzürk korku, ısfahan cevr (eziyet), nevâ lezzet ve ferahlık, uşşâk gülme, zirgüle uyku, sabâ yiğitlik, bûselik kuvvet, hüseynî barış, hicâz makamının da insana tevazu verdiği kaydedilmektedir (Kalender, 1987, 362). Tıp bilimciler tarafindan Avicenna olarak bilinen İbni Sinâ, tedavinin en etkili yollarından birinin hastanın aklî ve ruhî güçlerini arttırmak olduğunu ve ona hastalıkla daha iyi mücadele için cesaret vermek gerektiğini belirtmiştir. Bunların yanında hastanın çevresini sevimli ve hoşa gider hâle getirmenin ve ona en iyi musikiyi dinletmenin gerekliliğinden bahsetmiştir (Ak, 2018, 60).

Tarihte müziği hastane ortamında tedavi amaçlı kullanan ilk Türklerdir. Kındî'den başlayarak Farabi, İbni Sina ve Safiyyüddin Urmevî ile devâm eden ve belirli ses aralıklarının terkibiyle oluşan yeni makam anlayışı tedavi amaçlı bu hastanelerde kullanılmaya başlanmıştır. İlk kez Selçuklular zamanında açılmaya başlanan bu hastanelerin sayıları Osmanlı döneminde de çoğalarak farklı bölgelerde faaliyet göstermişlerdir (Turabi, 2021, 39).

İlk kurulan hastane olan ve Nureddin Hastanesi olarak bilinen bu müzikle tedavi merkezinde akıl hastaları için özel bir bölüm bulunmaktadır. Hem hekim hem de müzisyen olan Hekimbaşı Abdül Mecid Efdal Muhammed bin Abdullah elBahili'nin, akıl hastalarını müzikle tedavi ettiği bilinmektedir (Erer, Atıc1. 2010, 30).

Osmanlı döneminde tedavide müziğin kullanıldığı en özellikli hastane 1484 yılında Sultan II. Bayezid tarafından yaptırılan Edirne Dârüşşifâsıdır. Bu Dârüşşifâda akıl hastalarının müziğin yanında müsekkin türü ilaçlar ve güzel kokularla tedavi edildiği bilinmektedir. Müzik açısından akustiği düşünülerek Dârüşşifânın inşa edilmiş olması dikkat çekicidir. Evliya Çelebi, Seyahatnamesinde; bu Dârüşşifâda hânendelerin, neyzenlerin, kemânîlerin, musîkârîlerin, santûrîlerin ve ûdîlerin haftada üç gün fasıl yaptıklarından bahsetmektedir (Ak, 2018, 57-58).

Turkish Academic Research Review - Türk Akademik Araştırmalar Dergisi https://dergipark.org.tr/tr/pub/tarr 
482 Müzikle Tedavi: Tarihi, Gelişimi, Bağımlılıklarda Uygulanışı Ve Türkiye'deki Müzik Terapi Uygulamaları

Müzikle tedavi uygulamaları yapılan Selçuklu ve Osmanlı tedavi merkezleri şunlardır: Kayseri Gevher Nesibe Şifâhiyesi (1206), Sivas Divriği Dârüşşifâsı (1228), Amasya Dârüşşifâsı (1309), İstanbul Fatih Dârüşşifâsı (1470), İstanbul Süleymaniye Tıp Medresesi ve Şifâhanesi (1556), İstanbul Enderun Hastanesi ve Edirne Sultan II. Bayezid Dârüşşifâsı (1488) (Yücel, 2016, 5).

18. yy’e kadar Avrupa'da müzik tedavisinin Türkler'de olduğu gibi bilimsel olarak kullanıldığı pek söylenemez. Avrupa insanı şeytana, cine ve büyü hikâyelerine inanmıştır. Bu güçlerin etkilerinin şeytani müziğe bağlı olduğu kabul edilmiştir. Gizli Hristiyan tarikatlarına bağlı büyücüler yaptıkları müzik ve danslarla şeytanı canlandırdıklarını engizisyon mahkemelerinde itiraf etmiştir (Oruç, 1985, 5).

\subsection{Tarihte İlk Müzik Terapilerinin Klinik Ortamlarda}

\section{Kullanılmaya Başlanması}

Modern rehabilitasyon yöntemi olarak müzik terapi, II. Dünya Savaşı'ndan bu yana belirgin bir ivme ve gelişme kazanmıştır. (Leo Shatin, Wallace L. Kotter, Gladys Douglas-Longmore, 1962, 99). “Amerika'da müzikle tedavide ilk adımı atan Dr. Willer Van de Wall' dur. Wall 1920 yılında New York eyaletinin hastane ve hapishanelerinde, müziğin insan ruhu üzerindeki etkilerini araştırmıştır. Wall'a göre müziğin insan ruhundaki yatıştırıcı etkisi inkâr edilemez niteliktedir.” (Gençel, 2006, 698). Washington'daki Walter Reed hastanesinde ciddi anlamda psikolojik sıkıntıları olan gazilerin tedavisinde müzik terapileri uygulanmaya başlanmış ve olumlu sonuçlar elde edilmiştir (Glover, 1962, 53). Bunun bir örneği de II. Dünya savaşında Amerika'ya ait donanmada görev alan Ed'dir. Gemisine bir Japon Kamikaze uçağının saldırısı sonrasında vücuduna isabet eden mermiler ve patlamanın etkisiyle, Ed'in vücudu ağır hasar almıştı. Hastanede 2 ay kaldıktan sonra vücudu sabitlenmeden duramayacak kadar engelli olan ve derin bir sessizliğe bürünen Ed, tedavisinin bitiminden sonra Washington'daki müzik terapileri uygulanan akıl hastanesine gönderildi. Ed, terapiye başlamadan önce ara ara çığlıklar atan ve derin ürkütücü tepkileri olan biriydi. Terapinin sonlarına doğru her ne kadar başkalarıyla ilişki kurmakta biraz zorlanıp suratsız görünse de de, ara sıra gülümseyen biri haline gelmiş ve son hâli için müzik hocasına dâima müteşekkir olduğunu belirten ifadelerde bulunmuştur (Leo Shatin, Wallace L. Kotter, Gladys Douglas-Longmore, 1962, 100).

Elde edilen bu sonuçlar neticesinde Amerika'nın Manhattan ve California eyaletlerindeki bazı hastanelerinde de müzik terapileri, ruhsal hastalıkların tedavisinde yerini almıştır. California eyaletindeki yoğun müzik tedavilerinin 
uygulandığı Akıl Hastanesinde görev alacak terapistlere lisans derecesinde müzik terapi bilgilerine haiz olma zorunluluğu getirilmiş̧ir (Pikler, 1962, 26).

Müzikle terapi merkezleri $1945^{\prime}$ den sonra, Fransa'da ve İsveç'in Stokholm şehrinde enstitüsü olarak kurulmuştur. Fransa'da elektro akustik mühendisi olan Jocge Jost'a, 1954 y1lında, bir psikiyatri hastanesi tarafindan, müziğin bazı ruh hastalıklarında etkisini inceleme görevi verilmiştir (Kalender, 1990, 279). İngiltere'de ilk müzik tedavi merkezi yaklaşık 1950'li yıllarda İngiltere'nin büyük Akıl Hastalıkları Hastanesi olan Horton'da açılmış ve yapılan çalışmalarda olağan üstü başarılar sağlanmıştır. Uygulanan müzik terapinin bir parçası olan konser etkinliklerine katılmak ve müzik dinlemek, pek çok hastalar için, iyiye doğru bir gidişin başlangıcı olmuştur (Yiğitbaş, 1972, 327-328).

İçe dönük kişiliklere sahip otizmli çocukların dış dünyaya açılımında müzikten etkilendiklerini gören J. Louise Despert, 1947'de çalışmalarını başlatmış ve kayda değer veriler elde etmiştir. Bu veriler sonucunda Bergman, 1949'da Escalone, 1952'de Mahler, 1953'te Sherwin, 1959'da Settlage, 1964'te Rimland, ve 1966'da Robinson müzikle tedaviyi devam ettiren kişiler olmuştur (Oruç, 1985, 15).

"Bilim adamları, bedenin müziğe verdiği fiziksel cevapları incelemiş ve müziğin her şart ve ortamda bazı mekanizmaları harekete geçirdiğini tespit etmişler, farklı müzik türlerine farklı cevapların oluşabileceğini de keşfetmişlerdir.” (Boşnak, Kurt, Yaman, 2017, 35). Bu cevaplar bazen İtalyan annede olduğu gibi tesadüfen de ortaya çıkabilmektedir. İtalya'da yeni doğum yapmış bir anne bebeğine karşı nefret duyguları beslemeye başlamış ve bir süre sonra onu görmek istememiştir. Anneye uygulanan psikolojik tedavi esnasında tesadüfen "Trovotere" operasındaki bir arya kadını ağlatmaya başlamış ve arya bitince çocuğunu görmek istediği görülünce klinikte müzikle tedavi uygulamaları başlamış olur (Yiğitbaş, 1972, 327-328).

\subsection{Müzik Terapilerinin Uygulanabilmesi İçin Gereken Ön Şartlar}

Müzikle terapi yapılan bu merkezlerdeki veriler paylaşıldıkça içinde kısmen veya tamamen müziğin kullanıldığı terapi merkezleri açılmaya başlamıştır. $\mathrm{Bu}$ merkezlerde müzik, aktif ve pasif olarak uygulanmıştır. Pasif tedavilerin içinde müzik konserleri gibi sadece dinlemeye yönelik aktiviteler bulunmaktadır. Aktif tedavilerde ise hasta kişinin dâhil olduğu müzikle dans, müzik aleti öğrenimi, ritim uygulamaları gibi aktiviteler yer almaktadır. (Gençel, 2006, 704).

"Müziğin oluşturduğu fiziksel ve çevresel faktörlerde kişinin duygu durumu; zaman, mekân gibi kavramlardan etkilenebilir ve buna bağlı olarak değişiklikler gösterebilir.” (Boşnak, Kurt, Yaman, 2017, 35). Bu unsurlar yeterince

Turkish Academic Research Review - Türk Akademik Araştırmalar Dergisi https://dergipark.org.tr/tr/pub/tarr 
484 Müzikle Tedavi: Tarihi, Gelişimi, Bağımlılıklarda Uygulanışı Ve Türkiye'deki Müzik Terapi Uygulamaları

incelendikten sonra hasta ile temasa geçilmelidir. Müziğin de dâhil olduğu terapilerde başarılı sonuçlar alınabilmesi için önce hastanın bu tedavi yöntemini kabul etmesi gerekmektedir. Sonrasında hastanın dinî inancı, hayat felsefesi, yaşadığı kültüre göre müzik terapileri uygulanmalıdır (Boxberger, 1962, 126). Çünkü hasta bu psikolojik duruma içinde bulunduğu toplum içinde girmiştir. Kendisi de o toplumun bireylerinden biridir. Müzikle terapi yapılacaksa ilk önce kendi kültürünün müziği ile yapılmalıdır. Altınölçek; bireylerin müzik anlayışları, yaşamış oldukları toplumun sosyal ve kültürel yapısına ve almış oldukları eğitime bağlı olarak çeşitlilik gösterdiğini söylemektedir. Altınölçek’e göre; bazı bireyler kişisel veya sosyal ön yargıları nedeniyle bazı müzikleri kabul etmekte veya reddetmektedir (Gençel, 2006, s.702).

Yapılan araştırmalar, müziğgin ruh ve sinir hastalıkları başta olmak üzere birçok hastalığın gerek geleneksel gerekse bilimsel tedavi yöntemlerinde etkili bir tedavi aracı olarak kullanıldığını göstermektedir. Bu kapsamda her toplumun kendi inancı, sosyokültürel yapısı çerçevesinde müziğin bu yönünden faydalandığını söylemek mümkündür. Bu şekilde değerlendirildiğinde müzik, terapistin elinde değerli bir araç olacaktır.

\subsection{Müzik Terapilerinin Klinik Ortamlarda Farklı Hastalıklarda}

\section{Kullanılmaya Başlanması}

Teknolojinin ilerlemesi ile birlikte müzikle tedavide bazı tıbbi cihazlar, alana özgü geliştirilen ses-frekans ölçüm cihazları ve yeni geliştirilen metodlar sayesinde sadece ruhî bunalımda olan hastalar için değil aynı zamanda biyolojik ve fizyolojik rahatsızlıkların tedavisinde de terapilerin yapıldığı gözlemlenmektedir. Bunlardan birine örnek olarak Guy Berard tarafından geliştirilen işitsel algıya yönelik uygulanan metot verilebilir.

Berard Metodu; içinde müzik veya ses dalgalarının da etkin olarak kullanıldığı ve alg1 geliştirme yöntemi olarak kullanılan bir metottur. Tedavi edici ya da tıbbi bir yardımı olmasa da bu metotla günümüzde birçok insan bu metotla yaşadığı sorunların üstesinden gelebilmektedir. Uygulanan bu metotla hayatın her alanından herkes faydalanabilmektedir. Konuşma becerilerinde sıkıntısı olan, kekemelik, ad ve şekil, yüz hafızası zayıf olan ya da zayıflamaya başlayan unutkan kişilerde ve otizm hastalarında bu sorunların tedavi boyunca tedricen azaldığ gözlemlenmiştir. Bugün bu metot dünyada birçok klinikte uygulanmaktadır (Uçak, 2019, 53). Bu metotta müzik ve ses dalgaları için kullanılan farklı cihazlar bulunmaktadır. Bunun için geliştirilen Earducator ve Audiokinetron, hastalar 
üzerinde uygulanan ve tedavinin ayrılmaz parçası olan cihazlardır (Berard AİT, 2021).

20. yy'inin sonunda ve 21. yy'inin başlarında müzik terapisi uygulayan kliniklerde elde edilen veriler neticesinde, kanser hastalıklarının kemoterapi alımı sonucunda bulantı ve kusma şikayetlerinin azaltılması, yoğun bakımda ventilatöre bağlı yatan hastaların anxieteye (kaygı) şikayetlerinin minimum düzeye indirilmesi gibi durumlarda müzik terapi etkin bir şekilde kullanılmaya başlamıştır (Jiraporn, Porntip, Hanucharurnkul, Kredboonsri, 2008, 327-346).

Tens ve müzik Elektrostimülasyonu ile çeşitli ağrıları olan 24 hasta üzerine bir çalışma yapılmıştır. Bu hastalara belirli oranlarda Transkutan elektrik sinir stimülasyonu (TENS), Müzik Elektro Stimülasyonu (MES) ve plasebo (yalancı ilaç) tedavisi uygulanmıştır. Çalışma neticesinde TENS ve MES gruplarında ağrı düzeyi plasebo uygulanan gruba göre anlamlı derecede düşmüştür (Tekeoğlu, Şekeroğlu, Tarakçığlu, Adak, Kara, 1995, s. 100-103).

Alzheimer hastalarında da müzik tedavilerinin uygulanması sonucunda umut verici değerler kaydedilmektedir. Tayland'daki Mohidol Üniversitesinde yapılan çalışmada hastalara $40 \mathrm{~Hz}$. ses verilmiştir. A-B çapraz çalışma tasarımında denekler, 6 hafif, 6 orta, 6 şiddetli derecede 18 alzheimer katılımcısından oluşmaktaydı. Hastaların her biri 13 seansa katıldı: bir alım ve 12 tedavi. Deney sonucunda $40 \mathrm{~Hz}$. sesin, hafif ve orta derecedeki alzheimer hastalarında en güçlü etkiye sahip olduğu görülmüştür (Clements-Cortes, Ahonen, Freedman, Bartela, 2016,) (Jiraporn, Porntip, Hanucharurnkul, Kredboonsri, 2008, 346).

Müzikle tedavide diğer dikkat çeken çalışma, damak yarığı problemi nedeniyle konuşma güçlüğü olan çocuklar üzerinde yapılmıştır. Damak yarığı problemi olan çocuklarda konuşma esnasında nefeslerini burundan değil de ağızdan verildiği takdirde bir nebze başarıya ulaşılması hedeflenmiştir. Bunun için çocuklara klarnet üfleme tekniği ile birlikte içinde konuşmada zorlandıkları harflerin çoğunlukta olduğu şarkılar öğretildi. Deney sonucunda çocukların konuşmalarında anlamlı bir gelişme görülmüş ve motivasyonlarının yükseldiği kaydedilmiştir (Michel, 1962, 110-115).

\section{Bağımlıık ve Tedavi Şekilleri}

"Genel anlamı ile bağımlılık; bir nesneye, kişiye, ya da bir varlığa duyulan önlenemez istek, bir başka iradenin güdümü altına girme durumu olarak tanımlanabilir ve insanın bilişsel aktivitesi ile ilişkili patolojik bir davranışı yansıtır." (Gürsu, 2018, 17). Bağımlılık; madde bağımlılı̆̆ı ve davranışsal bağımlılık

Turkish Academic Research Review - Türk Akademik Araştırmalar Dergisi https://dergipark.org.tr/tr/pub/tarr 
486 Müzikle Tedavi: Tarihi, Gelişimi, Bağımlılıklarda Uygulanışı Ve Türkiye'deki Müzik Terapi Uygulamaları

olmak üzere ikiye ayrılmaktadır. "Madde Bağımlılığı, bireyin madde kullanımı sonucunda ortaya çıkacak olan zihinsel, davranışsal ve psikolojik semptomları bilmesine rağmen o maddeyi kullanmaya devam etmesi madde bağımlılı̆ıının en temel özelliği şeklinde tarif edilmiştir." (Gürsu, 2018, 17). "Madde bağımlıllğı tarihi olarak daha eskilere dayanırken, davranış bağımlılığı psikolojik ve psikiyatrik açıdan, nispeten yeni bir araştırma alanıdır.” (Bektaş, 2018, 147).

Bugün itibariyle baktığımızda o kadar çok bağımlılık çeşidi var ki, gelişmiş veya gelişmekte olan ülkeler, bağımlılık ile mücadelede inanılmaz boyutta finans kaynağı ayırmakta “...bağımlılık ile mücadele için yasal düzenlemelere gitmekte, strateji ve eylem planları düzenlemekte, aynı zamanda da kamu politikaları oluşturmaktadır.” (Yavuz, Çöpoğlu, 2018, 128). Bu kadar çok strateji, eylem planları ve kamu politikaları uygulanıyor olmasına rağmen sadece Amerika'da 2018 yılında 1.7 milyon kişinin tedavi aldığı bilinmektedir ve bu sayı her geçen yll artmaktadır (Yoes, Silverman, 2021, 61). Buna benzer bir örnekle, nüfusu yaklaşık 38 milyon olan Malezya'da 2018 yılında 17.474 bin yeni madde bağımlısı tespit edilmiş, 2012'de 10 bin civarında olan bu sayı 2016'da 22.923 bin olmuştur. 2016'da madde bağımlılı̆̆ından kendini gizleyen yaklaşık 8 bin civarında bağımlı bulunmaktadır (Amat, Johari, Najib, Jais, Pamidi, Mahyuddin, 2019, 181). Türkiye'de ise sadece 2017 yılında toplam 118.482 bin uyuşturucu olayı görülmüşken, 2018 yılında \%22,23 artış göstererek 144.819 bin olmuştur (Türkiye Uyuşturucu Raporu, 2019).

Madde ve davranışsal bağımlılıklar ile mücadelede Türkiye'deki Alkol ve Madde Bağımlılığı Tedavi ve Eğitim Merkezi (AMATEM) gibi pek çok merkezde tedavi şekilleri uygulanmaktadır. Bu yöntemler içinde ilaç tedavisi, bireysel terapi, grup psikoterapisi, bibliyoterapi, davranışçı terapiler, psikoeğitim ve aile danışmanlığı, uğraşı ve sanat terapisi, ve toplumsal beceri eğitimleri uygulanmaktadır (Amatem sıkça sorulan sorular, 2021). İster bir psikiyatri hastanesinde olsun, isterse tedavi sürecinin iyice yapılandırıldığı bir AMATEM'de olsun, yatarak tedavinin birincil amacı maddeden arındırmadır (detoksifikasyon). Arındırma, maddenin bırakılmasıyla birlikte ortaya çıkan yoksunluk belirtilerini baskılamak ya da azaltmak için ilaç kullanarak, kişiyi maddeden uzaklaştırma süreci olarak tanımlanabilir (Amatem tedavi ortamı, 2021).

Burada dikkatimizi çeken husus depresyon türü ilaç tedavisinin neredeyse birincil olarak kullanılmasıdır. Son yıllarda Geleneksel ve Tamamlayıcı Tıp (GETAT) merkezleri içinde, müziğin de etkin olarak kullanıldığı farklı tedavi merkezlerinin sayılarında dikkate değer bir artış yaşanmaktadır (Biçer, Balçık, 2019, 253). GETAT merkezlerinde depresyon türü ilaçlardan daha çok bitkisel ürünler, 
kültürlere göre yoga, akupunktur, sülük, apiterapi, hipnoz ve müzik terapileri gibi tedavi şekilleri uygulanmaktadır (Yüksel, Açıkgöz, Yüksel, Ayoğlu, Er, 2019, 277).

\subsection{Bağımlılık Tedavilerinde Müzik Terapi Uygulamaları}

"Müzikle tedavinin tıp bilimindeki birçok alanla ilişkili olduğu ve bu alanlarda kullanıldığı bilinmektedir. İnsan diğer sanat dallarına göre, müzikten daha çok etkilenmektedir. Müzik, ruhun çeşitli tepkilerini en iyi ifade eden bir sanattır. Bu özelliğinden dolayı da insanın ruhsal davranışlarını inceleyen psikoloji ile müzik arasında doğal bir bağ oluşmaktadır.” (Gençel, 2006, 701). "Çeşitli birçok araştırma, müziğin insanda fizyolojik ve psikolojik değişikliklere neden olduğunu belirlemiştir. Bugüne kadar yapılan araştırmalara bakıldığında klasik müzik, caz, pop/rock, etnik müzik, film müziği ve sentezlenerek araştırma amaçlarına göre oluşturulmuş müziklerin yoğunlukla kullanıldığı görülmüştür.” (Okay, Ece, 2019, 2). Müzikle terapi çalışmalarında insanda akıl, vücut ve ruh arasında bir denge oluşturmaktadır. Yapılan birçok çalışmada, ses ve müziğin ağrı duygusu ve kaygı hali üzerinde olumlu değişikliklere yol açtığını göstermiştir (Karamızrak, 2014, 54). Bu nedenle müzikle terapi çalışmalarında müziğin kullanımı, depresyonlarda, madde bağımlılıklarında, otizmli hastalarda, kardiyoloji bölümlerinde, kanser hastalarında, kumar bağımlılıklarında ve teknolojinin gelişmesi neticesinde ortaya çıkan teknolojik aletlerden kaynaklanan bağımlılıkların v.s tedavilerinde gün geçtikçe etkin bir şekilde artmaktadır.

Müzikle terapi alanında yapılan çalışmalarda elde edilen veriler bizlere müziğin çok yönlü araştırmalarda kritik bir rol oynayabileceğini ileri sürmektedir. Müzik, madde bağımlılığı olan hastaları motive etmede ve meşgul etmede, duyguları ve olumlu ruh hali değişikliklerini ortaya çıkarmada, stres ve kaygıyı azaltma gibi durumlarda kullanılabilmektedir (Baker, Libby, Genevieve, 2007, 322).

Madde bağımlılığında müzik terapisinin amacı; kişiyi madde bağımlılığından kurtarmak, bireye veya topluma zarar veren mevcut davranışların değiştirilmesini teşvik etmek, madde kullanım sorunlarına katkıda bulunan temel biyo-psiko-sosyal faktörlerin farkındalığını artırmaktır (Ghetti, 2004, 86).

W. S. Mathis, (2015)'te yaptığı bir araştırmada madde bağımlılarında müzik tedavisinin, uyuşturucu kullanımından etkilenen beyin bölgelerinde dopaminin artmasını engelleyecek ve madde özlemini azaltabilecek potansiyel bir estetik girdiye sahip olduğunu belirtmektedir. Mathis, Han ile yaptığı bir deneyde madde bağımlılı̆̆ı olan bir gruba müzik terapi uygulamış diğer bir gruba da parazit sesi (white noise) dinletmiştir. Müzik dinletilen grupta madde kullanım isteğinde bir

Turkish Academic Research Review - Türk Akademik Araştırmalar Dergisi 
488 Müzikle Tedavi: Tarihi, Gelişimi, Bağımlılıklarda Uygulanışı Ve Türkiye'deki Müzik Terapi Uygulamaları

azalma olduğunu gözlemlemişlerdir (Mathis and Han, 2017, 147). Buna benzer bir çalışmada ise madde bağımlılı̆̆ı olan gruba madde isteğini azaltmak için 3 farklı tedavi biçimi uygulanmıştır. Bu grupların birine sadece müzik, diğerine isteği azaltıcı ilaç ve diğer bir gruba da her ikisi uygulanmıştır. Sonuçta, sadece müzik dinletilen grupta maddeye karşı isteğin azaldığı verileri elde edilmiştir (Stamou, Chatzoudi, Stamou, Romo, and Graziani 2016, 45).

Carte ve Panisch'in 2020'de madde bağımlılığı hastalarına yönelik müzik terapisi uygulanan 12 adet deneyin sonuçlarını inceledikleri bir çalışma bulunmaktadır. Bu çalışma sonucunda dört deneyde anlamlı sonuçlar elde edilirken diğer 8 çalışmada kayda değer bir sonuç ortaya çıkmamıştır. Bunun nedeni de bu deneylerde kullanılan müzik dinlemeye maruz bırakılma, doğaçlama müzik uygulaması, besteleme ve eser analizi metodları gibi farklı metotların kullanılması olabilir. (Carte, Panisch, 2020, 1-18)

Müzik terapi uygulamalarında müzik aleti öğretimi ile tamamlayıcı tedavi girişimleri de deneylerde yer almaktadır. Bu çalışmada farklı müzisyenlerin ritim duygusunu ön plana çıkaran uygulamaları mevcuttur. "Mark Seaman and Earth Rhythms of West Reading" programı, "Ed Mikenas and the Lynchburg'1n Day" program1, “Myron Eshowsky'nin Shamanic Counseling Approach" program1, "Daniel Smith'in Shamanic Approach and Pilot Program at the Phoenix Shanti Group" isimli programlarında, ritim çalışmaya bağlı olarak bağımlılara davul çalmayla birlikte dans, yoga ve dinî müzik kullanılarak grup terapileri uygulanmıştır. Bunların ortak özellikleri ise bağımlılara maneviyatı güçlü tutmak için dinî söylemleri kullanıyor olmalarıdır. Bu uygulamalar irdelendiğinde içinde Şaman inancı gibi farklı inanç çalışmalarının dâhil olduğu davul çalma uygulamalarının, katılımcıların hayata pozitif bakmalarında, kendilerini daha rahat hissetmede, duygusal yönde iyileşme ve sosyaliteyi artırmada etkili olduğu sonucuna varılmıştır (Winkelman, 2003, 647-65).

Davranış bağımlılı̆̆1 içinde yer alan kumar bağımlılı̆̆1 da son yüzyılda tedavi edilebilir bağımlılıklar arasında yer almaktadır. Teknolojik gelişmeler sonucunda ortaya çıkan kumar makineleri, insanları felakete sürüklemekte, intihara varan sonuçlar gözlemlenmektedir. Kumar bağımlısını kaybedilmiş bir kişi olarak görmemek gerekir. Kumar bağımlılığı ahlâki değil tıbbi bir durumdur. Bu bağımlılıkların tedavisinde başta ilaç ve psikoterapiler uygulanmaktadır (Adnancoban kumar-hastaligi, 2021).

Yapılan klinik çalışmalar, müzik terapilerinin bu bağımlılıkta da uygulanabilir olduğunu göstermiştir. Bu konu üzerinde Jaakko Erkkilä ve Tuomas Eerola'nın "Kumar Bağımlılığında Müzikle Terapi Metotları” adlı çalışmaları 
bulunmaktadır. Tedavi 4 ardışık aşamadan oluşmuş ve 1 yıl sürmüştür. Gruplar 4 faz grubuna ayrılmıştır. Faz 1'e Physio-Acoustic "İnsanların ve hayvanların kulakta veya ilişkili merkezi sinirsel işitme yollarında meydana gelen akustik uyaranlara verilen yanıtların incelenmesi." (Physio-Acoustic, 2021) metodu uygulanmıştır. Faz 2'ye de farklı kombinasyonlu psikoterapik modeller, psikodinamik ve bilişsel gibi yöntemlerin yanı sıra sözlü müzik terapi de uygulanmıştır. Müzikle terapide; dinleme, müzikle rahatlama alıştırmaları ve dinlenilen müzik hakkında yorum içeren uygulamalar yapılmıştır. Faz 3, faz 1 ile aynıdır. Tek fark hastaların tedaviyi sürdürmeleri için ikna seanslarının olmasıdır. Faz 4 ise faz 2 ile aynıdır. Farkı ise faz 4'teki bağımlıları konser, tiyatro ve müze ziyaretleri gibi sosyal aktiviteleri içermesidir. Sonuçlara bakıldığında müzik terapi uygulanan faz 2 ve faz 4 'te kumar oynama sıklığı giderek azalmış ve son aşamada tedavi boyunca hiç kumar oynamayanların sayısı giderek artmıştır (Erkkilä ve Eerola, 2003, 1-18).

Gün geçtikçe madde ve davranışsal bağımlılıklarında müzik terapilerinin rolünün, veriler incelendiğinde dikkate değer bir anlam bulundurduğudur. Yeni geliştirilen metotlar ve görüntüleme cihazları sayesinde müziğin tedavi edici gücünden daha fazla yararlanılacağı düşünülmektedir.

\section{Türkiye'de Müzik Terapi Uygulamaları}

Tarihte ilk defa hastane ortamında müzik tedavi uygulamalarının yapıldığı bir medeniyete sahip olmamıza rağmen gelinen noktada hiç te iç açıcı bir noktada olmadığımız görülmektedir. Türkiye'de müzikle tedavi konusunda klinik ortamlarda yapılan çalışmalar, Avrupa ve Amerika gibi ülkelere nazaran yeterli olmayıp bu konuda akademik alanda eğitimi bulunmamaktadır. "Ülkede eğitim verecek yeterli akademik uzman kadrosu olmadığ için sertifika programı açılamamaktadır." (Kayım, 2017, 53).

21. yy'in başlarında Türkiye'de özel teşebbüslerle açılan Türk Tedavi Musikisi Uygulama ve Araştırma Grubu TÜTEM, Türk Musikisini Araştırma ve Tanıtma Grubu TÜMATA, Üsküdar Üniversitesi'ne bağlı olarak Müzik Terapi Uygulama ve Araştırma Merkezi MÜTEM, 2014 yılında ise bir grup araştırmacı tarafından Ankara'da Müzik-Terapi Derneği MÜZTED ve Sağlık Bakanlığı bünyesinde kurulan geleneksel tamamlayıcı ve alternatif tıp uygulamaları daire başkanlığı haricinde resmi bir kurum ya da özel klinik bulunmamaktadır (Uçaner, Jelen, 2015, 39-40). Ancak son yıllarda bazı özel kliniklerde laboratuvar ortamında olmasa da müzikle terapi uygulamaları artış göstermektedir. Fakat bu çalışmaların içinde madde bağımlılı̆̆ tedavileri ile ilgili bir çalışma bulunmamaktadır. Yapılan çalışmaların ve buna bağlı olarak yazılan makalelerin genelde, otizm, kardiyoloji,

Turkish Academic Research Review - Türk Akademik Araştırmalar Dergisi 
490 Müzikle Tedavi: Tarihi, Gelişimi, Bağımlılıklarda Uygulanışı Ve Türkiye'deki Müzik Terapi Uygulamaları

palyatif bakım, kanser gibi hastalar üzerinde yapılan bazı çalışmalar olduğu göze çarpmaktadır. $\mathrm{Bu}$ çalışmaların çoğunluğu literatür taraması mahiyetinde olup bazıları klinik ortam düzeyindedir.

Son çeyrek asırda ismini sıkça duyduğumuz alzheimer hastalığının tedavisi ile ilgili yapılan çalışmaların Türkiye'de de yoğunlaştı̆̆ını görmekteyiz. Bu konu her ne kadar nöropsiklojinin dalı olsa da uygulanan metotlar içinde müziğin de kullanıldığı çalışmalar artmıştır. Bu konuda alzheimer hastalarına nihâvend makamının uygulandığı bir yüksek lisans çalışması yapılmıştır. Çalışma yaklaşık 3 ay süre içinde, Türkiye Alzheimer Derneği Eskişehir Şubesi Huzurevi ve Yaşlı Bakım Merkezi'nde, yatmakta olan dâhil edilme ölçütlerine uygun 30 hasta ile yapılmıştır. Verilerin değerlendirilmesinde Mann- Whitney U testi, Kruskal Wallis testi, Pearson Ki-kare, Student's-t testi kullanılmıştır. Makam olarak çoğu 20.yy'da bestelenmiş Bir İhtimal Daha Var, Unutturamaz Seni Hiçbir Şey, Kimseye Etmem Şikayet, Gel Güzelim Çamlıcaya gibi şarkılardan oluşan nihâvend makamı uygulanmıştır. Deney sonucunda; anlamlı bir şekilde hastaların müzik dinletisi sırasında diğer arkadaşları ile uyum güçlüğünde azalma olduğu gözlemlenmiştir (Kiyak, 2019, 72).

2018 yılında yapılan bir çalışma; ileride müziğin ve ses frekanslarının şimdiye kadar klinik ortamda çalışılmamış bazı hastalıklara yol gösterecek mahiyettedir. $\mathrm{Bu}$ araştırmada; müzik eğitimi almamış üniversite öğrencilerinin dinledikleri müzik türlerine karşı duygularını öğrenmek ve dinlenilen müzik türünün beyindeki theta, alpha ve SMR dalgalarına olan etkisi Nexus-10 cihazı yardımı ile ölçülmüştür. Deneyde 20 erkek üniversite öğrencisi bulunmaktadır ve katılımcılara Klasik Türk Müziği, Türk Halk Müziği, Klasik Batı Müziği, jazz, rock, rocknroll ve rap müzikleri dinletilmiştir. Çalışma sonunda istatistiksel bir anlamlı sonuç çıkmasa da betimsel anlamda bazı değişiklikler gözlemlenmiştir (Kurşunet, Sazak, 2018, 149-165).

Karagözoğlu ve ekibinin “Müzik Terapisinin ve Rehberli Görsel İmgenin Kemoterapiye Bağlı Anksiyete Ve Bulantı-Kusma Üzerindeki Etkileri” adlı çalışmalarında müzikle terapi uygulanmıştır. Çalışma sonucunda; terapinin, kemoterapiye bağlı bulantı ve kusmanın şiddetini ve süresini önemli ölçüde azalttı̆̆g görülmüştür. Hastaların \%40'ında beklenen bulantının ve \%55'inde beklenen kusmanın olmadığı tespit edilmiştir (Karagözoğlu, Tekyaşar ve Yılmaz, 2013, s.39$50)$.

$\mathrm{Bu}$ örnekler düşünüldüğünde Türkiye'de yapılan klinik merkezlerinde müzik terapi çalışmalarının Türk Müzik kültürüne göre eksik ya da hatalı olduğu gözlemlenmektedir. Kıyak'ın yapmış olduğu çalışmada alzheimer hastalarına neden 
nihâvend makamının dinletildiği açıklanmamıştır. Kurşunet ve Sazak’ın çalışmalarında kullandığı müzik çeşitleri içinde sadece 2 Türk müziği formu kullanılmış olup neden bu formlar ve makamlar olduğu belirtilmemiştir. Ayrıca bu iki çalışmada makam seçimleri hatalı gözükmektedir. Muhayyer Kürdî makamının yaklaşık 150 yıllık bir geçmişi vardır ve kadim makam tesirleri anlatımında bu makam hiç geçmemektedir. Nihâvend mâmı ise birkaç eserde zikredilmiştir.

Selçuklu ve Osmanlı döneminde hastalıklar için önerilen makamlarla Türkiye'de müzik terapilerinde uygulanan makamlar ve hastalıklar karşılaştırıldığında büyük yönde tutarsızlık olduğu görülmektedir. Bu konuda Can ve Yılmaz’ın (2019) da yaptığı “Türkiye’de Müzik Terapi Uygulamalarında Kullanılan Müzikler” adlı çalışmada, Türkiye’de 2019 yılına kadar klinik ortamda uygulanan çalışmalardaki müzik formları ve makamlar tablo halinde sunulmuştur. Çalışmaların içerikleri de incelendiğinde çoğu rastgele seçilmiş müzik formları ve makamlar olduğu tespit edilmiştir. Ayrıca hastalıklar, makamlar ve canlı uygulanan terapilerdeki müzik aletleri birbirleriyle örtüşmemektedir.

Makamların tedavide kullanımı konusunda literatür incelendiğinde kişinin ruh haline, inancına, tenine, sevdiği müzik aletinin türüne ve hatta günün belirli vakitlerine göre tedavinin şekil aldığı bilinmektedir. İbni Sinâ'nın müzikle tedavi uygulamaları incelendiğinde vakitlere göre makam uygulamaları; seherde rehâvî, sabah vakti hüseyni, güneş doğduktan yükselinceye kadarki zamanda rast, öğleye kadarki vakitte buselik veya zirefkend, öğle vakti zengüle ve uşşâk, ikindiye kadar hicaz, ikindi vakti akşam vakti ısfahan ve nevâ, yatsı vaktinde büzürk ve uyku halinde muhtelif makamlar şeklinde olmuştur (Turabi, 1985, 33). Ayrıca, esmer tenlilerde ırak makâmı, buğday tenlilerde ısfahan makâmı, şarışın tenlilere rast karalı makamlar ve beyaz tenlilere küçek makamı tavsiye edilmiştir (Güvenç, 1985, 2526).

Türkiye'de müzik terapi alanında zengin bir literatür bilgisi ve bu bilgiye sahip müzik alanında akademisyenler bulunmaktadır. Terapilerde literatürden ve akademisyenlerden faydalanıldığı takdirde klinik deneylerde daha farklı sonuçlar çıkabilir.

\section{Sonuç}

Tarihte gelişmiş bir medeniyete sahip olan birçok toplumun, müziği etkin bir şekilde kullandığ1 ve geliştirmeye çalıştığı görülmüştür. Geçmişte müziğin görevi daha çok ruhani olup, ruhsal hastalıkları tedavide ve kendi inançları çerçevesinde kullanıldığ 1 tespit edilmiştir.

Turkish Academic Research Review - Türk Akademik Araştırmalar Dergisi https://dergipark.org.tr/tr/pub/tarr 
492 Müzikle Tedavi: Tarihi, Gelişimi, Bağımlılıklarda Uygulanışı Ve Türkiye'deki Müzik Terapi Uygulamaları

Selçuklu ve Osmanlı medeniyetlerinin makam bilgileriyle, ruhsal hastalıkların tedavisinde kullandıkları müzik terapileri için açılan şifahaneler gelişmiş toplumlara örnek olduğu kanaatine varılmıştır.

20. yy'de müzikle terapi hususunda çalışmaların artması neticesinde metotlar gelişmiş ve farklı tekniklerle farklı hastalıkların tedavilerine başlanmıştır. Ruhsal hastalıklar başta olmak üzere, otizm hastalarında, kardiyoloji bölümünde, cerrahi müdahalelerin öncesinde ve sonrasında müzik terapilerinin anlamlı bir başarıya sahip olduğu sonucuna varılmıştır.

Müzikle tedavi çalışmalarının belki de en dikkat çekici olanı ise bağımlılıkta ve özellikle madde bağımlıların tedavisinde kullanılıyor olmasıdır. Çalışmada madde veya kumar gibi bağımlılara ahlaki telkinlerden daha ziyade tıbbi gereksinimlerinin olduğu anlaşılmıştır. Yapılan çalışmalarda müziğin, madde bağımlılarına uygulanan anti-depresan türü ilaçlar kadar etkili bir yöntem olduğu görülmüştür. Metotlar geliştikçe, teknoloji kaynaklı kumar bağımlılıklarında bile müzik terapilerinin etkili olduğu tespit edilmiştir.

Son dönemde insanların ruhsal çöküntüye sebep olan ruhsal ve fiziksel kaynaklı hastalıkların tedavisinde müzikle birlikte yoga türü meditasyonların, mistisizmin ve inanç eksenli öğretilerin etkin bir şekilde kullanıldığı ve başarılı sonuçlar elde edildiği anlaşılmıştır.

Müzikle terapi konusunda kadim bir tecrübeye sahip olan ve Osmanlı medeniyetinin devamı niteliğinde olan Türkiye'de ise müzikle tedavinin gereken değeri görmediği, klinik deneylerde kullanılan müziğin de kadim makam tedavilerindeki uygulamalara dayalı olmadığı saptanmıştır. Müzikle tedavi konusundaki çalışmaların çoğunun literatür taramasına dayalı olduğu sonucuna varılmıştır.

\section{Öneriler}

Türkiye'de yapılacak müzikle terapi deneylerinde özellikle Türk Müziği ve formları kullanılmalıdır. Ayrıca bu uygulamalarda sanatını çok iyi icrâ eden icrâcılardan ve türk müziği makam ve usûl kuramına hâkim müzik bilimcilerinden yararlanılmalıdır.

Türk Müziği’nde makamların etkisi üzerine çalışmaları bulunan akademik personelden ve çalışmalarından faydalanılmalıdır.

Yüksek Eğitim Kurumu (YÖK) tarafından, Türk Müziği makam ve tedavileri üzerine araştırma yapan akademisyenlerin görevlendirildiği sertifikalı müzik terapist eğitim merkezleri açılmalı, gerektiğinde terapistlerin en az yüksek lisans deresinde olmaları sağlanmalıdır. Bu konu ile ilgili gerekli yönetmelik değişiklikleri yapılmalıdır. 
Müzikle tedavi için Devlet politikası oluşturulmalı, müzikle tedavi merkezlerinde sertifikalı terapistlerin görev alması sağlanmalı ve müzik terapistinin Türkiye'de bir meslek olması hususunda girişimler yapılmalıdır.

\section{Kaynakça}

Adnancoban kumar hastalığı. (2021, 5 Mayıs). Erişim adresi: https://www.adnancoban.com.tr/kumar-hastaligi

Ak, A. Ş. (2013). Avrupa ve Tük İslam Medeniyetinde Müzikle Terapi Tarihi Gelişim ve Uygulamaları. Ötüken Yayınları. İstanbul.

Ak, A. Şahin. (2018). “Türk-İslam Medeniyetinde Müzikle Tedavi”. TÜRKTOB Dergisi.Say1: 25: 57-61

Amat, M. I., Johari, K. S. K., Najib, N. M., Jais, H. M.., Pamidi, S., Mahyuddin and Muhammad Khairi. (2019). "Experience of Recovering Addicts Undergoing The 7 Steps Recovery İn Addiction Program (7-SRA) as an Aftercare Treatment." Religion: Ş Revista De Ciencias Sociales Y Humanidades. s. 180-188.

Amatem sıkça sorulanlar. (2021, 7 Mayıs). Erşim adresi: https://www.boylamamatem.com/amatem-sikca-sorulanlar/

Amatem tedavi ortamı. (2021, 7 Mayıs). Erşim adresi: https://www.boylamamatem.com/tedavi-ortami/

Andrew G. P. (1962). Music As An Aid In Psychotherapy. Eleventh Book Of Proceedings Of The National Associaton For Music Therapy. (Editor Erwin h. Schneider, ph.d.) Published by the NationalAssociation for Music Therapy. Lawrance, Kansas America. 11: 23-39.

Bektaş, M. (2018). Davranışsal Bağımlılık: Tanımı, Türleri ve Sınıflandırılması. Bir Kamu Politikası Olarak Bă̆ımlılıkla Mücadele. (Editörler: Hamza Ateş, Ahmet Koçak). Nobel Akademik Yayıncılık. Ankara. s. 147-159.

Berard AİT. (2021, 23 Nisan). Erişim adresi: https://berardaitwebsite.com/wpcontent/uploads/How-do-Berard-AIT-and-Music-Therapy-Differ.pdf

Biçer, İ., Balçık, P. Y. (2019). “Geleneksel Ve Tamamlayııı Tıp: Türkiye ve Seçilen Ülkelerinin İncelenmesi”. Hacettepe Sağllk İdaresi Dergisi. 22 (1): 245-257.

Boşnak, Mehmet. Kurt, Akif Hakan. Yaman, S. (2017). "Beynimizin Müzik Fizyolojisi”. KSÜ Tip Fak Dergisi. 12 (1): 35-44.

Turkish Academic Research Review - Türk Akademik Araştırmalar Dergisi https://dergipark.org.tr/tr/pub/tarr 
494 Müzikle Tedavi: Tarihi, Gelişimi, Bağımlılıklarda Uygulanışı Ve Türkiye'deki Müzik Terapi Uygulamaları

Boxberger, R. (1962). Historical Bases for The Use of Music in Therapy. Eleventh Book Of Proceedings Of The National Associaton For Music Therapy. (Editor Erwin h. Schneider, ph.d.) Published by the NationalAssociation for Music Therapy. Lawrance, Kansas America. s. 125-166

Carter, T. E. and Panisch, L. S. (2020). "A Systematic Review of Music Therapy for Psychosocial Outcomes of Substance Use Clients" International Journal of Mental Health and Addiction. s. 1-18.

Chontichachalalauk, J. Malathum, P., Hanucharurnkul, S. and Charn K. (2008). "The Effect of Music Therapy on Anxiety, Physiological Responses, and Weaning Parameters in Patients during Weaning from Mechanical Ventilation.” Rama Nurs J.ournal. 14 (3): 327-346.

Claire M. G. (2004). Incorporating Music Therapy into the Harm Reduction Approach to Managing Substance Use Problems. Music Therapy Perspectives. 22(2): 84-90.

Clements-Cortes, A., Ahonen, H., Freedman, H. and Bartela, L. (2016). "ShortTerm Effects of Rhythmic Sensory Stimulation in Alzheimer's Disease: An Exploratory Pilot Study". 10th European Music Therapy Conference. Journal of Alzheimer's Disease. 52(2): 651-660.

Demirci, M. (2021). Türk Musikisi Tarihi. Türk Din Musikisi El Kitabı. (Ed. Ahmet Hakkı Turabi). Grafiker Yayınları. 6. Baskı. İstanbul.

Düzenli, P. (2014). İslâm Kültür Tarihinde Mûsikî. Kayıhan Yayınları. 2. Baskı. İstanbul.

Erkkilä, J. and Eerola, T. (2003). "Music Therapy Methods İn The Treatment Of Gambling Addiction”. Music Therapy Today. 4(3): 1-18.

Felicity A. B., Libby M. G. and Genevieve A. D. (2007). "Music therapy and emotional exploration: Exposing substance abuse clients to the experiences of non-drug-induced emotions". The Arts in Psychotherapy. 34(4): 321-330.

Gençel, Ö. (2006). “Müzikle Tedavi”. Kastamonu Eğitim Dergisi. 14(2): 697-706.

Gönül, M. ve Yıldırım, M. (2017). “İslâm Dîninde Mûsikîye Karşıt Görüşlere Mûsikî Penceresinden Bir Bakış”. ISTEM Dergisi. 15(30): 257-270.

Gürsu, O. (2018). Bă̆ımlılık ve Din: Nöropsikolojik Bir Yaklaşım. DEM Yayınları. 1. Basım. İstanbul.

Gürsu, O., (2020). Inancın Bă̆ımlılık Karşısındaki Fonksiyonu. Bütün Yönleriyle Bağımlılık ve Sosyal Hizmet Kitabı (Editör. Sinan Zavalsız). Grafiker Yayınları Ankara. s. 269-299 
Güvenç, R. O. (1985). Türklerde ve Dünyada Müzikle Ruhi Tedavinin Tarihçesi ve Günümüzdeki Durumu. Doktora Tezi. İstanbul Üniversitesi Cerrahpaşa Tip Fakültesi. İstanbul.

Haşmet A. (1998). Bir İletişim Aracı Olarak Müzik ve Müzikle Tedavi Yöntemleri.

Doktora Tezi, Anadolu Üniversitesi Sosyal Bilimler Enstitüsü.Yayınlanmamış Olan Doktora Tezi, Eskişehir.

Kalender, R. (1987). “Türk Musikisi'nde Kullanılan Makamların Tesirleri”. Ankara Üniversitesi Illahiyat Fakültesi Dergisi. 29(1): 361- 375.

Kalender, R. (1990). "Ruh Hastalıkları Tedavisinde Musiki". Ankara Üniversitesi Ilahiyat Fakültesi Dergisi. 31(1): 361- 375.

Kaygısız, M. (1999). Müzik Tarihi, Başlangıcından Günümüze Müziğin Evrimi. Kaynak Yayınları, İstanbul.

Kayım, G. (2017). Dünya'da Müzik Terapi Tarihi Ve Eğitimi. Yüksek Lisans Tezi. Haliç Üniversitesi Sosyal Bilimler Enstitüsü Türk Musikisi Anasanat Dalı Türk Müziği Yüksek Lisans Programı. İstanbul.

Kıyak, M. (2019). Alzheimer Hastalarında Müziğin Uyum Güçlüğ̈̈nü Azaltmadaki Etkisi. Yüksek Lisans Tezi. Eskişehir Osmangazi Üniversitesi Sağlık Bilimleri Enstitüsü Hemşirelik Anabilim Dalı. Eskişehir.

Kurşunet, D. D. K. ve Sazak, Nilgün. (2018). "Tetha, Alpha, Smr, Beyin Dalgalarının Müzik Türleriyle Olan Etkileşimi: Bir Nexus-10 Eeg Çalışması.” Online Journal Of Music Sciences. 3(1): 149-165.

Karagozoglu S., Tekyasar F. ve Y1lmaz F.A. (2013). Effects Of Music Therapy And Guided Visual İmagery On Chemotherapy-İnduced Anxiety And NauseaVomiting. Clin Nurs Journal. 22(1-2): 39-50.

Karamızrak, N. (2014). "Ses ve Müziğin Organları İyileştirici Etkisi”. Koşuyolu Kalp Dergisi. 17(1): 54-57.

Leo, S., Wallace L., Kotter, G. and Douglas L. (1962). Music Therapy For Schizophrenics. Eleventh Book Of Proceedings Of The National Associaton For Music Therapy. (Editor Erwin h. Schneider, ph.d.) Published by the NationalAssociation for Music Therapy. Lawrance, Kansas America. s. 99104.

Michel, D. E. (1962). Music Therapy in Cleft Palate Disorders. Eleventh Book Of Proceedings Of The National Associaton For Music Therapy. (Editor Erwin h. Schneider, ph.d.) Published by the NationalAssociation for Music Therapy. Lawrance, Kansas America. s.109-115

Turkish Academic Research Review - Türk Akademik Araştırmalar Dergisi https://dergipark.org.tr/tr/pub/tarr 
496 Müzikle Tedavi: Tarihi, Gelişimi, Bağımlılıklarda Uygulanışı Ve Türkiye'deki Müzik Terapi Uygulamaları

Mathis, W. S. (2015). “The Neuroscientific Basis For Aesthetic Preference As An Intervention For Drug Craving Associated With Addiction". Journal of Addiction Research \& Therapy. 6(1): 3-9.

Mathis, W. S. and Han, X. (2017). "The Acute Effect Of Pleasurable Music On Craving For Alcohol: A Pilot Crossover Study". Journal of Psychiatric Research, 90: 143-147.

Murphy, K. M. (2017). "Music Therapy in Addictions Treatment: A Systematic Review Of The Literature And Recommendations For Future Research". Music\& Medicine. 9(1): 15-23.

Okay, H. H. ve Ece, A. S. (2019). "Psikoloji Araştırmalarında Duygu Tanımlanması İçin Kullanılan Müzik Eserleri Ve Özellikleri”. Akademikbakış Dergisi. 75: 1-12.

Physio-Acoustic. (2021, 29 Nisan). Erişim adresi: https://encyclopedia2.thefreedictionary.com/Physiological+Acoustics\#: :text $=\% 5 \mathrm{~B} \% \mathrm{E} 2 \% 80 \% 9 \mathrm{Afiz} \% \mathrm{C} 2 \% \mathrm{~B} 7 \% \mathrm{C} 4 \% 93 \% \mathrm{C} 2 \% \mathrm{~B} 7 \% \mathrm{C} 9 \% 99$, pathways $\% 20$ of $\% 20$ humans $\% 20$ and $\% 20$ animals.

Ray G. (1962). New Concepts In Psychiatric Treatment. Eleventh Book Of Proceedings Of The National Associaton For Music Therapy. (Editor Erwin h. Schneider, ph.d.) Published by the NationalAssociation for Music Therapy. Lawrance, Kansas America. s. 48-49.

Sezer E. ve Elif A. (2010). "Selçuklu ve Osmanlılarda Müzikle Tedavi Yapılan Hastaneler”. Uludă̆ Üniversitesi Tıp Fakültesi Dergisi 36 (1): 29-32.

Stamou, V., Chatzoudi, T., Stamou, L., Romo, L. and Graziani, P. (2016). "Musicassisted Systematic Desensitization For The Reduction Of Craving İn Response To Drug-Conditioned Cues: A Pilot Study." The Arts in Psychotherapy. 51:36-45.

Tarhan, D. E. (2020). "Pythagoras Felsefesinde Müzik Ve Matematik İlişkisi Üzerine". Akademik Felsefe Dergisi, Ekim 15: 1-22.

Tekeoğlu, İ., Şekeroğlu, M., Tarakçıoğlu, M. Adak, B. ve Kara, M. (1996). “Ağrılı Hastalarda Tens Ve Müzik Elektrostimülasyonun Kan Endorfin Düzeylerine Etkileri”. Romatizma Dergisi. 11(2): 100-103.

Turabi, A. H. (1985). İbn Sînâ'nın Kitâbü’ş Şifâsı'nda Mûsikî. Doktora Tezi. Marmara Üniversitesi İlahiyat Fakültesi Sosyal Bilimler Enstitüsü İslam Tarihi ve Sanatları Bilim dalı. İstanbul.

Turabi, Ahmet Hakkı (2021). İlk Dönem İslâm Dünyası'nda Mûsikî Çalışmaları. Türk Din Musikisi El Kitabı. (Ed. Ahmet Hakkı Turabi) Grafiker Yayınları. 6. Bask1. İstanbul. 
Türkiye Uyuşturucu Raporu. (2019). Erşim adresi: http://www.narkotik.pol.tr/kurumlar/narkotik.pol.tr/ 2019-TurkiyeUyusturucu-Raporu.pdf

Uçak, D. (2019). "Müziksel Bellek Geliştirmede Berard Metodu Kullanımının İncelenmesi”. "İnsan Yaşamında Müzik” konulu X. Hisarll Ahmet Sempozyuти Bildiri Kitabl. s. 53-71.

Yavuz, Ö. ve Çöpoğlu, M. (2018). Türkiye'de Bă̆ımlılık Sorunu Ve Bă̆ımlılıkla Mücadele: Politika Analizi Çerçevesinde Bir Değerlendirme. Bir Kamu Politikası Olarak Bağımlılıkla Mücadele. (Editörler: Hamza Ateş, Ahmet Koçak). Nobel Akademik Yayıncılık. Ankara. s. 127-146.

Yiğitbaş, M. Sadık (1972). Musiki ile Tedavi. Yelken Matbaası. İstanbul.

Yoes. M. and Silverman, M. J. (2021). "Expectancy Theory of Motivation and Substance Use Treatment: Implications for Music Therapy". Music Therapy Perspectives. 39: 61-68.

Yücel, H. (2016). "Türk İslam Medeniyetinde Müzikle Tedavi Yöntemlerinin Uygulandığı Şifahaneler: Amasya Darüşşifası”. TURAN-SAM Uluslararası Bilimsel Hakemli Dergisi. Cilt: 8(29): 52-62.

Yüksel, N. A., Açıkgöz, C. B., Yüksel, C., Ayoğlu, F. N. ve Er, T. (2019). “Hekimlerin Geleneksel Ve Tamamlayıcı Tıp Uygulamalarına Bakış Açısı”. ESTÜDAM Halk Să̆lı̆̆ Dergisi. 4 (3): 276-286.

Winkelman, M. (2003). “Complementary Therapy for Addiction: Drumming Out Drugs". American Journal of Public Health. 93(4): 647-653.

Turkish Academic Research Review - Türk Akademik Araştırmalar Dergisi https://dergipark.org.tr/tr/pub/tarr 